\title{
lloperidone in the treatment of schizophrenia: an evidence-based review of its place in therapy
}

This article was published in the following Dove Press journal:

Core Evidence

14 December 2016

Number of times this article has been viewed

\section{Fernanda S Tonin' \\ Astrid Wiens ${ }^{2}$ \\ Fernando Fernandez- \\ Llimos $^{3}$ \\ Roberto Pontarolo}

'Pharmaceutical Sciences Postgraduate Program, ${ }^{2}$ Department of Pharmacy, Federal University of Parana, Curitiba, Brazil; ${ }^{3}$ Department of Social Pharmacy, Faculty of Pharmacy, Research Institute for Medicines (iMed.ULisboa), Universidade de Lisboa, Lisbon, Portugal
Correspondence: Roberto Pontarolo Department of Pharmacy, Pharmaceutical Sciences Postgraduate Program, Federal University of Parana, Av. Prof. Lothario Meissner 632, Curitiba 80210-170, Brazil Tel +55 4I 33604094

Email pontarolo@ufpr.br
Introduction: Schizophrenia is a chronic and debilitating mental disorder that affects the patient's and their family's quality of life, as well as financial costs and health care settings. Despite the variety of available antipsychotics, optimal treatment outcomes are not always achieved. Novel drugs, such as iloperidone, can provide more effective, tolerable and safer strategies.

Aim: To review the evidence for the clinical impact of iloperidone on the treatment of patients with schizophrenia.

Evidence review: Clinical trials, observational studies and meta-analyses reached a common consensus that iloperidone is as effective as haloperidol, risperidone and ziprasidone in reducing schizophrenia symptoms. Similar amounts of adverse events and discontinuations were observed with iloperidone compared to placebo and active treatments. Common adverse events are mild and include dizziness, hypotension, dry mouth and weight gain. Iloperidone can induce extension of QTc interval, and clinicians should be aware of its contraindications. In long-term trials, iloperidone also showed promising safety and tolerability profiles. The low propensity to cause akathisia, extrapyramidal symptoms (EPS), increased prolactin levels or changes to metabolic laboratory parameters support its use in practice. Results showed that iloperidone prevents relapse in stabilized patients, with a time to relapse superior to placebo and similar to haloperidol. Patients using a prior antipsychotic (eg, risperidone and aripiprazole) can easily switch to iloperidone with no serious impact on safety or efficacy. However, the acquisition costs of iloperidone may hamper its use. Further evidence comparing iloperidone with other antipsychotics, and pharmacoeconomic studies would be welcome.

Place in therapy: Considering just the clinical profile of iloperidone, it represents a promising drug for treating schizophrenia, particularly in patients who are intolerant to previous antipsychotics, as well as being suitable as first-line therapy. Cost-effectiveness comparisons are needed to justify its use in clinical practice.

Keywords: iloperidone, schizophrenia, clinical practice, evidence-based

Core evidence clinical impact summary for iloperidone in schizophrenia

\begin{tabular}{|c|c|c|}
\hline Outcome measure & Evidence & Implications \\
\hline \multicolumn{3}{|c|}{ Disease-oriented evidence } \\
\hline Schizophrenia & From clinical trials and & lloperidone arises as a potential alternative \\
\hline pathophysiology & observational studies: & to treat schizophrenia. However, since \\
\hline and iloperidone & moderate & the pathophysiology of the disease is not \\
\hline \multirow[t]{2}{*}{ mechanism of action } & & fully elucidated, there are some gaps in the \\
\hline & & literature concerning drugs activities. \\
\hline
\end{tabular}

(Continued) 


\begin{tabular}{|c|c|c|}
\hline $\begin{array}{l}\text { (Continued) } \\
\text { Outcome measure }\end{array}$ & Evidence & Implications \\
\hline $\begin{array}{l}\text { lloperidone as } \\
\text { therapeutic choice }\end{array}$ & $\begin{array}{l}\text { From clinical trials, } \\
\text { observational studies and } \\
\text { meta-analyses: clear }\end{array}$ & $\begin{array}{l}\text { lloperidone is an optimal alternative } \\
\text { as monotherapy for the treatment of } \\
\text { schizophrenia, due its proven efficacy } \\
\text { and promising safety profile, particularly } \\
\text { for patients who are intolerant to prior } \\
\text { treatments. }\end{array}$ \\
\hline \multicolumn{3}{|c|}{ Patient-oriented evidence } \\
\hline $\begin{array}{l}\text { Reduction in } \\
\text { positive and negative } \\
\text { symptoms: acute } \\
\text { efficacy }\end{array}$ & $\begin{array}{l}\text { From clinical trials and } \\
\text { meta-analyses: clear }\end{array}$ & $\begin{array}{l}\text { lloperidone was more effective than } \\
\text { placebo and similar to haloperidol, } \\
\text { risperidone and ziprasidone in several } \\
\text { psychometric scales and in symptoms } \\
\text { assessment. }\end{array}$ \\
\hline $\begin{array}{l}\text { Maintenance of } \\
\text { effectiveness and } \\
\text { safety }\end{array}$ & $\begin{array}{l}\text { From clinical long-term } \\
\text { trials: clear }\end{array}$ & $\begin{array}{l}\text { lloperidone proved to have long-term } \\
\text { efficacy and favorable safety profile } \\
\text { compared to placebo and haloperidol. }\end{array}$ \\
\hline $\begin{array}{l}\text { Prevention of relapse } \\
\text { in stabilized patients }\end{array}$ & $\begin{array}{l}\text { From clinical trials: } \\
\text { moderate }\end{array}$ & $\begin{array}{l}\text { Few studies have evaluated this outcome. } \\
\text { Iloperidone is better than placebo and } \\
\text { equivalent to haloperidol in time to relapse. }\end{array}$ \\
\hline Adverse events & $\begin{array}{l}\text { From clinical trials, } \\
\text { observational studies and } \\
\text { meta-analyses: clear }\end{array}$ & $\begin{array}{l}\text { lloperidone is an alternative to avoid } \\
\text { elevation in EPS and prolactin levels. } \\
\text { The incidence of weight gain and other } \\
\text { side effects (dizziness, orthostatic } \\
\text { hypotension, dry mouth, sedation, } \\
\text { extension of QTc interval) are common } \\
\text { but can be prevented by drug titration and } \\
\text { monitoring. }\end{array}$ \\
\hline $\begin{array}{l}\text { Adherence with } \\
\text { treatment }\end{array}$ & $\begin{array}{l}\text { From clinical trials, } \\
\text { observational studies and } \\
\text { meta-analyses: moderate }\end{array}$ & $\begin{array}{l}\text { Some patients may discontinue treatment } \\
\text { due to adverse events or inefficacy. } \\
\text { However, drugs seem to be well tolerated } \\
\text { among patients, especially for long periods. }\end{array}$ \\
\hline \multirow[t]{2}{*}{$\begin{array}{l}\text { Effectiveness in } \\
\text { treatment-resistant } \\
\text { schizophrenia } \\
\text { Economic evidence }\end{array}$} & $\begin{array}{l}\text { From clinical trials: } \\
\text { insufficient }\end{array}$ & $\begin{array}{l}\text { Clozapine remains the therapeutic option } \\
\text { for treating resistant schizophrenia. }\end{array}$ \\
\hline & $\begin{array}{l}\text { Pharmacoeconomic } \\
\text { studies: insufficient }\end{array}$ & $\begin{array}{l}\text { No formal cost-effectiveness analysis has } \\
\text { been conducted. }\end{array}$ \\
\hline
\end{tabular}

\section{Scope, aim and objectives}

Iloperidone $\left(\right.$ Fanapt $^{\circledR}$, Zomaril $\left.^{\circledR}\right)$ is an atypical antipsychotic, whose primary mechanism of action is the antagonism of certain receptors, such as dopamine D2 and serotonin 5-hydroxytryptamine (5HT) receptor 2A. Iloperidone was recently approved in the US for treating schizophrenia, became available in the market from early 2010 , and is currently under evaluation for approval in Europe. This antipsychotic is being promoted due to its promising efficacy and safety profile compared to other therapeutic options available worldwide. The choice of a specific drug should be based on individual preference, prior treatment response, clinical risk factors and adherence history.

Since there are some published studies that assessed potential effects of iloperidone in patients with schizophrenia, it is valuable to gather all available information to provide a broader view over this topic, thus increasing the precision estimate of results and contributing toward clinical decision-making.

The objective of this review was to assess the impact of iloperidone on the treatment of schizophrenia and establish, where possible, its place in therapy, highlighting the advantages and disadvantages of this drug for clinical practice.

\section{Methods}

\section{Search and eligibility criteria of studies for clinical and economic evidence}

A systematic review was performed according to PRISMA (Preferred Reporting Items for Systematic Reviews and MetaAnalyses) and Cochrane Collaboration recommendations. ${ }^{1,2}$ 


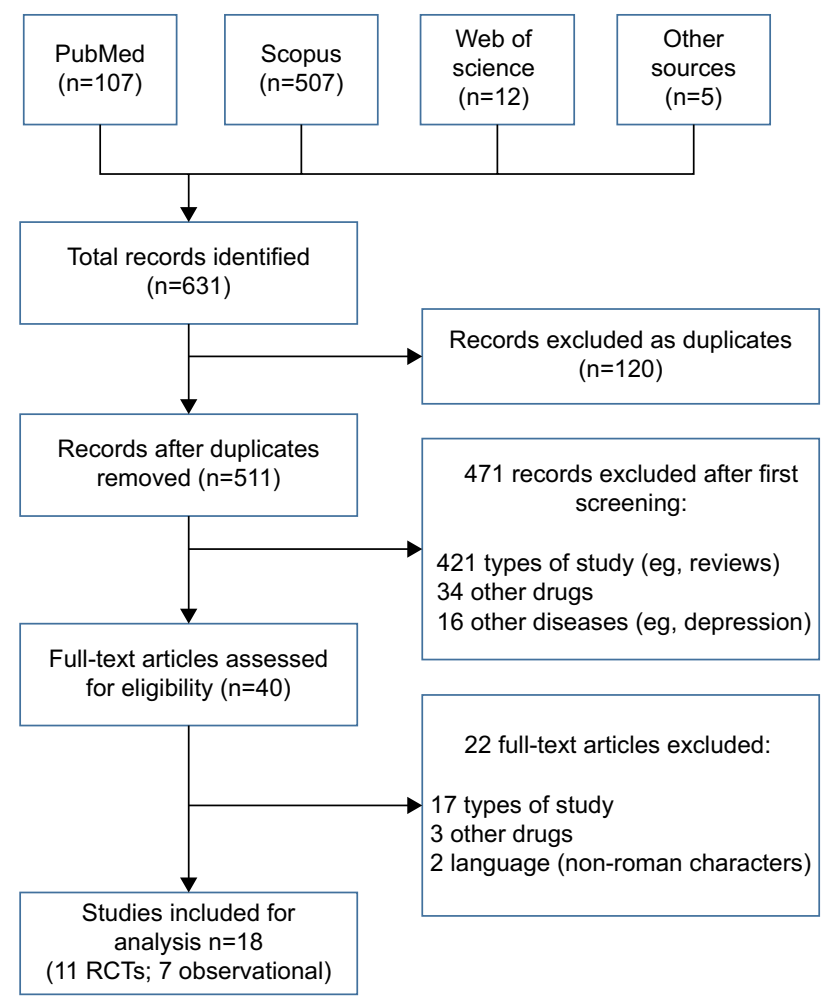

Figure I Flowchart of the systematic review process and final included studies. Abbreviation: RCTs, randomized controlled trials.

Two reviewers performed all steps individually before reaching a consensus (FST and AW). Discrepancies were decided by a third author (FFL). We searched for articles in the following electronic databases without limits for time frame or language (updated in September 2016):

- PubMed, www.ncbi.nlm.gov

- Scopus, www.scopus.com

- Web of Science, www.webofscience.com Additional sources and the reference lists of the included studies were also consulted:

- National Institute for Health and Clinical Excellence (NICE), www.nice.org.uk

- Database of Abstracts of Reviews of Effects (DARE), National Health Service (NHS) Economic Evaluation Database (NHSEED), Health Technology Assessment (HTA), www.york.ac.uk/inst/crd/darehp.htm

- Clinical trial registries, www.clinicaltrials.gov

The following search terms were employed, together with Boolean operators AND or OR: iloperidone; Fanapt; Zomaril; HP-873; schizophrenia, schizophrenic*; dementia. We included studies assessing the drug intervention iloperidone alone or in combination with other pharmacological or nonpharmacological interventions, regardless of dosage, in patients diagnosed with any stage of schizophrenia and/or related psychiatric disorders (no restriction of gender or age). For clinical evidence on the health-related outcomes of iloperidone, we primarily considered two types of studies: experimental trials (randomized clinical trials [RCTs] and extension studies) and observational studies (eg, case report and case series). Collected data were related to efficacy/ effectiveness of iloperidone (eg, drug response, psychometric scales assessment), its tolerability and safety-related outcomes (eg, adverse events). The flowchart of the systematic review process (records identified, included and excluded registers and reasons for exclusions) is shown in Figure 1.

\section{Results}

\section{Overview of the disease}

Schizophrenia is a chronic, debilitating and complex mental disorder with a heterogeneous and multifactorial pattern caused by different genetic, epigenetic, developmental and environmental risk factors. There are challenges to fully understand the causes and pathogenesis of this disorder and to develop new, effective and acceptable treatments. ${ }^{3,4}$

Psychosis corresponds to the most familiar cluster of the positive symptoms of schizophrenia, which may include hallucinations, delusions and thought or movement disorders. The positive symptoms tend to relapse and remit, although some patients have residual long-term psychotic symptoms. ${ }^{5,6}$ Negative symptoms are associated with disruptions to normal emotions and behaviors (eg, flat affect and poverty of speech). These symptoms are harder to recognize as part of the disorder and can be mistaken for depression or other conditions. ${ }^{3,5,7}$ For some people, cognitive symptoms may appear as poor executive functioning, difficulty focusing and problems with working memory. ${ }^{8-10}$

Diagnosis of schizophrenia usually occurs in young adults, based on symptoms outlined in the Diagnostic and Statistical Manual of Mental Disorders (DSM-V), and is not usually associated with laboratory results. ${ }^{7,8}$ To meet the criteria for diagnosis, the patient must have experienced at least two of the positive and/or negative symptoms, with at least one of the symptoms being delusions, hallucinations or disorganized speech. Continuous signs of the disturbance must persist for at least 6 months to be associated with marked impairment of functioning and not be better explained by another clinical condition. Early diagnosis is important to reduce the risk of a full-blown episode already in a premorbid stage or the risk of an impending relapse. ${ }^{3,6,7}$

The median incidence of schizophrenia in general population is $\sim 1 \%$, with 15.2 per 100,000 persons affected..$^{11,12}$ This disorder affects both genders equally, despite being prone to 
occur earlier in men, and the effects can be long term and pervasive, with relapse being common. Although some variation by race or ethnicity has been reported, no racial differences in the prevalence of schizophrenia have been positively identified. ${ }^{12,13}$ The first episode of psychosis usually occurs in late adolescence or early adulthood, but it is frequently preceded by a prodromal phase or a so-called at-risk mental state., ${ }^{4,13}$

Worldwide, schizophrenia falls into the top 10 medical disorders causing disability, and, apart from personal distress, this disease has a huge socioeconomic burden, especially in terms of indirect costs, such as social support. ${ }^{3,12,14}$ In the US, the economic burden of schizophrenia was estimated at $\$ 155.7$ billion in 2013 ( $\$ 134.4$ billion- $\$ 174.3$ billion based on sensitivity analyses) and included excess direct health care costs of $\$ 37.7$ billion (24\%), direct non-health care costs of $\$ 9.3$ billion ( $6 \%$ ) and indirect costs of $\$ 117.3$ billion $(76 \%) .{ }^{15}$ In England, schizophrenia costs $£ 11.8$ billion per year, with around a third of this figure accounted for by direct expenditure on health and social care. ${ }^{4}$

Anatomic, neurotransmitter and immune system abnormalities have been implicated in the pathophysiology of schizophrenia. It seems that disruption of brain development is caused by genetic or environmental factors, or both. ${ }^{6,16}$ Dysfunction of dopaminergic neurotransmission contributes to the genesis of positive symptoms, but other evidence highlights widespread and variable involvement of other brain areas and circuits. Disturbances of synaptic function might underlie abnormalities of neuronal connectivity, but the precise nature, location and timing of these events are uncertain. ${ }^{17,18}$ The first clearly effective antipsychotic drugs, chlorpromazine and reserpine, were structurally different from each other, but they shared antidopaminergic properties. However, hypodopaminergic and hyperdopaminergic activities in the mesolimbic and mesocortical systems - leading, respectively, to negative and positive symptoms - may coexist. Moreover, newer antipsychotic drugs are able to block both dopamine D2 and serotonin (5HT) receptors. Clozapine is probably the most effective drug and is a particularly weak dopamine D2 antagonist. Thus, other neurotransmitters, such as norepinephrine, serotonin and gamma-aminobutyric acid (GABA), are involved. Some studies focused on the $N$-methyl-D-aspartate (NMDA) subclass of glutamate receptors, since its antagonism can lead to psychotic symptoms. ${ }^{17-20}$ Some neuroimaging studies show differences in some areas between the brains of those with schizophrenia and those without the disease (eg, decrease of volume of temporal and hippocampus areas; abnormalities in neocortical and limbic regions). ${ }^{21-23}$ Other, not mutually exclusive, theories include a deficit in myelin or white matter, association with cannabis use and genetic evidence of susceptibility genes. ${ }^{24-27}$ Furthermore, immune function is disturbed in schizophrenia, which may result in overexpression of inflammatory cytokines and subsequent alteration of brain structure and function. Inflammation might be related to both psychopathology and other disturbances in patients with schizophrenia, since insulin resistance and metabolic alterations are common in these patients. $^{20,28,29}$ Schizophrenia is also correlated with poor physical health, including higher rates of obesity, diabetes, hypertension and cardiovascular disease. ${ }^{16,30}$

At present, treatment of schizophrenia mainly consists of a combination of medical, psychological and psychosocial strategies; however, a pressing need for more effective treatments and delivery of services still exists. ${ }^{4,7}$ Antipsychotic medications, also known as neuroleptics or major tranquilizers, reduce the positive symptoms of schizophrenia and prevent relapses. Conventional or first-generation antipsychotics (FGAs) are primarily D2 blockers (eg, haloperidol and chlorpromazine) and have long been used to treat positive symptoms. However, they are usually associated with several adverse events, such as higher rates of extrapyramidal symptoms (EPS), namely, dystonia, parkinsonism, akathisia, sedation and anticholinergic side effects. Atypical or secondgeneration antipsychotics (SGAs) bind primarily, to different degrees, to both the $\mathrm{D} 2$ receptor and the 5HT2A receptor and may act at other receptors. ${ }^{5,9,10,31}$ A range of SGAs, including risperidone, olanzapine, aripiprazole, quetiapine and ziprasidone, are available worldwide. ${ }^{32-35}$

Efficacy for negative, depressive and cognitive symptoms appears to be determined by the extent to which the drug may improve these other domains or exacerbate EPS and anticholinergic effects. In contrast to their broadly similar efficacy, antipsychotics differ markedly in their propensity to cause various adverse effects. ${ }^{34,36}$ Although SGAs have generally been believed to be associated with a lower risk of EPS but a higher risk of metabolic adverse effects (eg, weight gain), the substantial variation in these and other side effects among agents within both classes indicates that it is not clinically useful to make a categorical distinction between FGAs and SGAs. Both classes of drugs can lead to hyperprolactinemia, orthostatic hypotension, gastrointestinal distress and blood dyscrasias. Thus, choice of antipsychotic medication should be based on individual preference, prior treatment response, risk factors and adherence history. ${ }^{34,36-38}$ Furthermore, the control of the disease is often incomplete, and some $20-30 \%$ of patients are considered refractory (not responsive to at least two different treatments). Despite 
decades of effort, clozapine remains the most effective agent in otherwise non-responsive patients. ${ }^{6,35}$

Novel drugs are constantly introduced to provide better treatments. Iloperidone has been accepted on the market after 12 years of premarketing evaluation and was approved by the US Food and Drug Administration (FDA) in May 2009, becoming available for use in early 2010. Recently (2013), the European Medicines Agency (EMA) has accepted evaluation of this drug application..$^{30,37,39}$

This drug is a piperidinylbenzisoxazole derivative, a tertiary amine whose primary mechanism of action is within the subtypes of combined D2/5HT2A antagonism, with greater affinity for the serotonin receptor (Ki value $5.6 \mathrm{nM}$ ), as well as for dopamines D2 and D3 (Ki values 6.3 and $7.1 \mathrm{nM}$, respectively) and noradrenergic A1 receptors ( $\mathrm{Ki}$ value $0.36 \mathrm{nM}$ ). Iloperidone has low affinity for serotonin 5HT1A, dopamine D1 and histamine $\mathrm{H} 1$ receptors (Ki values 168 , 216 and $437 \mathrm{nM}$, respectively) and no appreciable affinity ( $\mathrm{Ki}$ value $>1,000 \mathrm{nM}$ ) for cholinergic muscarinic receptors. ${ }^{39-41}$ This pharmacodynamic profile with low affinity to $\mathrm{H} 1$ and M1 receptors would lead to minimal sedation, cognitive impairment and mild weight gain. The extremely low binding at cholinergic receptors suggests a low risk of anticholinergic symptoms (eg, blurred vision and dry mouth), as well as a lower EPS liability. ${ }^{42,43}$

Pharmacokinetic studies have determined that iloperidone, formulated as solid tablets, is well absorbed orally, with a bioavailability of $96 \%$, and is extensively metabolized in the liver via CYP2D6 and CYP3A4. Peak serum iloperidone values were seen within 2-4 hours of administration. Iloperidone has a half-life of 13.5-14 hours and reaches a steady-state concentration within 3-4 days of initial administration. Initial dose is usually of $1 \mathrm{mg}$ orally twice a day, with a target dose ranging between 6 and $12 \mathrm{mg}$ twice a day and maximum dose of $24 \mathrm{mg} /$ day. ${ }^{35,39}$

\section{Clinical evidence}

After performing our systematic search, 631 records were retrieved and 511 were screened by title and abstract reading. A total of 40 records were considered for full-text appraisal, and, of these, 18 studies were suitable for final analysis: eleven RCTs (two of them being long-term trials) and seven observational studies (case reports and case series) (Figure 1). The main characteristics of the studies are provided in Tables 1 and 2. All studies involved patients diagnosed with schizophrenia or related disorder or psychosis and were mainly conducted in USA $(n=10)$, followed by India $(n=7)$. Studies have compared the use of iloperidone (doses rang- ing from 2 to $24 \mathrm{mg} /$ day) with placebo and/or active drugs (haloperidol, risperidone or ziprasidone). Overall, RCTs were well designed and properly reported randomization and/or blinding and patient dropouts (mean Jadad score of 3.2). Some records were grouped during the report, since they reported data from the same RCTs. All RCTs were sponsored by pharmaceutical industries (Vanda; Novartis) and properly declared conflicts of interest.

\section{Efficacy measures}

The measurement of the efficacy of drugs in clinical trials is usually carried out with psychometric scales. The Positive and Negative Syndrome Scale (PANSS) is commonly used to assess the severity of illness in patients with schizophrenia. There are 30 items in total, which are rated 1-7 (with 7 being most severe). The PANSS is identified by subscales: PANSS$\mathrm{T}$ is used to identify the total score, while PANSS-P is for positive symptom score, PANSS-N (negative symptoms) and PANSS-GP (general psychopathology score), which includes items not considered in the positive or negative symptoms scales. The Brief Psychiatric Rating Scale (BPRS) is another rating scale used to assess the severity of illness in schizophrenia. The BPRS is derived from the PANSS and consists of 18 items. Finally, the Clinical Global Impressions (CGI) is a 7-point Likert scale commonly used in psychiatric studies to assess overall patient functioning. Specific subscales used are the CGI-S (severity) and CGI-C or CGI-I (change or improvement). The higher the score, the worse the severity of the disease. ${ }^{44-46}$

\section{Short-term studies on iloperidone efficacy}

We identified six Phase III trials that assessed the acute efficacy of iloperidone for schizophrenia, as well as two more long-term trials (Table 1).

Cutler et al ${ }^{47-50}$ randomized 593 patients with schizophrenia (adults with mean age of $40 \pm 10.3$ years) in a 2:1:1 fashion under double-blind conditions to iloperidone ( $24 \mathrm{mg} /$ day), ziprasidone (160 mg/day) or placebo. Iloperidone was dosed twice daily $(1,2,4,6,8,10$ and $12 \mathrm{mg})$ over days 1-7. Ziprasidone was chosen as the active comparator because its adverse effect profile and titration schedule are similar to iloperidone. The evaluated outcomes were changes in the measured scales, PANSS-T and subscales, as well as in CGI-S and BPRS scores during 4 weeks (1 week of drugs titration and 3 weeks of fixed-dose treatment). Improvement from baseline in PANSS-T was observed in patients treated with iloperidone ( -12.0 points, $P<0.01$ versus placebo), as 
Table I Characteristics of included RCTs and extension trials

\begin{tabular}{|c|c|c|c|c|c|c|}
\hline Study & Treatment & $\mathbf{N}$ & Study design & Location & Age (years) & $\%$ Males \\
\hline $\begin{array}{l}\text { RCT } \\
\text { Cutler et al }{ }^{47} \\
\text { Lavedan et } \mathrm{al}^{48} \\
\text { Thompson et al }{ }^{49} \\
\text { Volpi et al }{ }^{50}\end{array}$ & $\begin{array}{l}\text { - lloperidone } 12 \mathrm{mg} 2 \times / \text { day } \\
\text { - Ziprasidone } 80 \mathrm{mg} 2 \times / \text { day } \\
\text { - Placebo }\end{array}$ & 593 & $\begin{array}{l}\text { Prospective, multicenter, } \\
\text { randomized, Phase III, } \\
\text { double-blind, placebo- } \\
\text { and ziprasidone- } \\
\text { controlled trial }\end{array}$ & USA, India & $40 \pm 10.3$ & 79.6 \\
\hline $\begin{array}{l}\text { RCT } \\
\text { Potkin et } \mathrm{al}^{51}(\mathrm{I})\end{array}$ & $\begin{array}{l}\text { - lloperidone } 4 \mathrm{mg} / \text { day } \\
\text { - lloperidone } 8 \mathrm{mg} / \text { day } \\
\text { - lloperidone } 12 \mathrm{mg} / \text { day } \\
\text { - Haloperidol } 15 \mathrm{mg} / \text { day } \\
\text { - Placebo }\end{array}$ & 621 & $\begin{array}{l}\text { Multicenter, } \\
\text { randomized, double- } \\
\text { blind, placebo- } \\
\text { controlled trials }\end{array}$ & USA & $38-40$ & 71.2 \\
\hline $\begin{array}{l}\text { RCT } \\
\text { Potkin et } \mathrm{al}^{51}(2)\end{array}$ & $\begin{array}{l}\text { - lloperidone 4-8 mg/day } \\
\text { - Iloperidone } 10-16 \text { mg/day } \\
\text { - Risperidone 4-8 mg/day } \\
\text { - Placebo }\end{array}$ & 616 & & & $38-40$ & 70.5 \\
\hline $\begin{array}{l}\text { RCT } \\
\text { Potkin et } \mathrm{al}^{51} \text { (3) }\end{array}$ & $\begin{array}{l}\text { - lloperidone } 12-16 \mathrm{mg} / \mathrm{day} \\
\text { - lloperidone } 20-24 \mathrm{mg} / \text { day } \\
\text { - Risperidone } 6-8 \mathrm{mg} / \text { day } \\
\text { - Placebo }\end{array}$ & 706 & & & $37-40$ & 62.0 \\
\hline $\begin{array}{l}\text { RCT } \\
\text { Citrome et al }\left.\right|^{55} \\
\text { Weiden et } \mathrm{al}^{56}\end{array}$ & $\begin{array}{l}\text { - lloperidone } 12-24 \mathrm{mg} / \text { day gradual } \\
\text { switch } \\
\text { - Iloperidone } 12-24 \mathrm{mg} / \text { day } \\
\text { immediate switch } \\
\text { Initial therapies were risperidone or } \\
\text { olanzapine or aripiprazol }\end{array}$ & 500 & $\begin{array}{l}\text { I2-week, open-label, } \\
\text { randomized trial }\end{array}$ & USA & $43.3 \pm 11.0$ & 67.0 \\
\hline $\begin{array}{l}\text { RCT } \\
\text { Potkin et al }{ }^{53}\end{array}$ & $\begin{array}{l}\text { - lloperidone } 8 \mathrm{mg} 2 \times / \text { day } \\
\text { - lloperidone } 12 \mathrm{mg} 2 \times / \text { day } \\
\text { - lloperidone } 24 \mathrm{mg} / \text { day } \\
\text { - Ziprasidone } 80 \mathrm{mg} 2 \times / \text { day } \\
\text { - Quetiapine } 375 \mathrm{mg} 2 \times / \text { day }\end{array}$ & 158 & $\begin{array}{l}\text { I2-week, open-label, } \\
\text { randomized trial }\end{array}$ & USA & $18-65$ & Not reported \\
\hline $\begin{array}{l}\text { RCT } \\
\quad \text { Weiden et a }{ }^{54}\end{array}$ & $\begin{array}{l}\text { - lloperidone 4-12 mg 2x/day } \\
\text { - Placebo }\end{array}$ & 303 & $\begin{array}{l}\text { REPRIEVE study; } \\
\text { randomized, double- } \\
\text { blind placebo-controlled } \\
\text { trial }\end{array}$ & USA, India, Ukraine & $38.3 \pm 11.2$ & 58.7 \\
\hline $\begin{array}{l}\text { Extension trial } \\
\text { Cutler et al }{ }^{57}\end{array}$ & $\begin{array}{l}\text { - lloperidone } 12 \mathrm{mg} / \text { day } \\
\text { - lloperidone } 24 \mathrm{mg} / \text { day } \\
\text { - Placebo }\end{array}$ & 173 & $\begin{array}{l}25 \text {-week, open-label } \\
\text { extension trial }\end{array}$ & USA, India & $39.9 \pm 10.3$ & 76.3 \\
\hline $\begin{array}{l}\text { Extension trial } \\
\text { Kane et } \mathrm{al}^{58}\end{array}$ & $\begin{array}{l}\text { - lloperidone } 12 \mathrm{mg} / \text { day } \\
\text { - Haloperidol } 12 \mathrm{mg} / \text { day }\end{array}$ & 489 & $\begin{array}{l}\text { Prospective, } \\
\text { randomized, } \\
\text { multicenter, open-label } \\
\text { flexible-dose, extension } \\
\text { phase }\end{array}$ & $>3$ countries & $39.9 \pm 10.7$ & 62.3 \\
\hline
\end{tabular}

Note: $* P$ values $<0.05$ versus comparators.

Abbreviation: RCT, randomized controlled trial; BPRS, Brief Psychiatric Rating Scale; CGI-S, Clinical Global Impressions-severity; PANSS, Positive and Negative Syndrome Scale; T, total; P, positive; N, negative; GP, general psychopathology; EPS, extrapyramidal symptoms; ECG, electrocardiogram; REPRIEVE, A Randomized Trial of lloperidone for Prevention of Relapse in Schizophrenia.

well as ziprasidone ( -12.3 points, $P<0.05$ versus placebo). Moreover, iloperidone demonstrated significant improvement compared to placebo on the BPRS $(P<0.05)$, PANSS-P $(P<0.001)$, PANSS-N $(P<0.05)$ and CGI-S $(P<0.01)$.

Potkin et $\mathrm{al}^{51}$ reported the results from three 6-week, double-blind, active- and placebo-controlled studies in patients with schizophrenia or schizoaffective disorder (aged 37-40 years). In the first trial, 621 patients were randomized to iloperidone (4, 8 or $12 \mathrm{mg} /$ day), haloperidol (15 mg/day) or placebo. The primary outcome measure was change from baseline in the PANSS-T score, where improvement was observed in the iloperidone $12 \mathrm{mg}$ /day group compared to pla- 


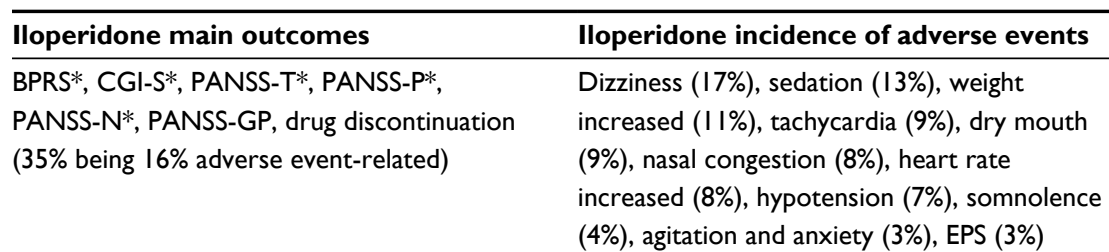

Combined analyses: BPRS*, CGI-S*, PANSS-T*, Not evaluated

PANSS-P*, PANSS-N*, PANSS-GP*, drug

discontinuation, (I) $60.7 \%$, (2) $48.0 \%$, (3) $44.5 \%$

\begin{abstract}
Conclusion
Similar amount of adverse events and relevant changes on disease scales were observed with both active treatments. lloperidone was effective, safe and well tolerated in schizophrenic patients with acute exacerbation.

At least one iloperidone dosing group in each study demonstrated significantly better efficacy than placebo. Comparable efficacy score reductions were observed mainly for iloperidone 20-24 mg/day versus those receiving haloperidol or risperidone. These trials indicate that iloperidone is effective in schizophrenia.
\end{abstract}

CGI response rates: gradual switch: $17.5 \%$ (week 2), gradual switch: 8I.2\% (week I2), immediate switch: $26.1 \%$ (week 2), immediate switch: $84.4 \%$ (week I2)

Assessment of heart rate-corrected QT interval, drug discontinuation related to adverse events: $3 \%$

Relapse rate: $17.9 \%$, time to relapse: 139 days, PANSS-T*, drug discontinuation $(50.3 \%$ being $3.2 \%$ adverse event-related)

PANSS-T and CGI-S: no signal of worsening, laboratory parameters (glycemia, lipids): normal values, drug discontinuation $(56.9 \%$ being $24.4 \%$ adverse event-related)

PANSS, CGI-S, BPRS: no signal of worsening, laboratory parameters (glycemia, lipids): normal values, drug discontinuation $(36.4 \%$ being $3.8 \%$ adverse event-related)
Reported as: gradual switch and immediate switch, respectively, dizziness $(8.8 \%$ and $14.2 \%$ ), dry mouth ( $9.2 \%$ and $13.1 \%$ ), fatigue ( $4.2 \%$ and $2.7 \%)$, insomnia (3.3\% and $6.5 \%)$, nasal congestion ( $4 \%$ and $2 \%$ ), nausea $(4.2 \%$ and $4.2 \%$ ), palpitations (1.3\% and $3.8 \%$ ), sedation (3.8\% and $3.8 \%)$, somnolence $(5.8 \%$ and $4.6 \%$ ), weight increase ( $3 \%$ and $2 \%$ ) ECG abnormalities ( $21 \%$ ), akathisia (8\%), EPS (8\%), psychosis (2\%)

Dizziness (1 I.6\%), somnolence (8.3\%), dry mouth $(6.8 \%)$, headache $(6.4 \%)$, insomnia (5.6\%), weight increase (5.4\%), nausea (5.1\%), schizophrenia $(2.4 \%)$

Headache (13.9\%), weight increase (9.2\%), dizziness $(6.9 \%)$, nausea $(6.4 \%)$, sedation (6.4\%), insomnia (5.2\%), nasopharyngitis (4.6\%), dry mouth (4.0\%), somnolence (3.5\%), psychotic disorder (3.5\%), retrograde ejaculation (1.7\%), suicidal $(0.6 \%)$ Insomnia (21.1\%), headache $(8.6 \%)$, anxiety (8.1\%), agitation (6.7\%), dizziness (5.8\%), akathisia (3.5\%), tremor (3.3\%), bradykinesia (1.3\%), dystonia (I.I\%), EPS ( $0.6 \%)$, death $(0.5 \%)$
Switching to iloperidone can be accomplished either with a gradual crossover or immediate discontinuation of the prior antipsychotic; however, the immediate-switch method is associated with greater proportion of initial dizziness.

No patients experienced QTc changes of clinical concern ( $>\mathrm{Q} 500 \mathrm{~ms}$ ). The only cardiovascular adverse events with iloperidone were nonconcentration-dependent tachycardia that was mild in most patients and did not lead to further sequelae.

Flexible dosing of iloperidone with a modal dose of $12 \mathrm{mg} /$ day was effective in preventing relapse in subjects previously stabilized on iloperidone. The adverse event profile showed low EPS. This study further supports the long-term safety and tolerability of iloperidone for schizophrenia, including its favorable effect on metabolic laboratory parameters and low propensity to cause akathisia or EPS.

lloperidone is equivalent to haloperidol in time to relapse and presented a better profile in the EPS Rating Scale scores. The long-term efficacy and favorable safety profile of iloperidone make this drug a suitable option for maintenance therapy. cebo ( -9.9 versus -4.6 points; $P<0.047)$ and for haloperidol versus placebo $(-13.9$ versus -4.6 points; $P<0.001)$. Moreover, significant improvement in the iloperidone $12 \mathrm{mg} /$ day group was noted in the BPRS scale $(P<0.042$ against placebo).

In the second trial, 616 patients were randomized to iloperidone (4-8 mg/day), iloperidone (10-16 mg/day), ris- peridone (4-8 mg/day) or placebo. Significant improvement from baseline on the primary outcome total BPRS score was seen in the iloperidone $4-8 \mathrm{mg}$ /day group $(P<0.012$ versus placebo), $10-16 \mathrm{mg} /$ day group $(P<0.001$ versus placebo $)$ group and the risperidone group $(P<0.001$ versus placebo). Furthermore, statistically significant improvement on the 
Table 2 Characteristics of included observational studies

\begin{tabular}{|c|c|c|c|c|c|c|c|c|c|}
\hline Study & Treatment & $\mathbf{N}$ & $\begin{array}{l}\text { Study } \\
\text { design }\end{array}$ & Location & $\begin{array}{l}\text { Age } \\
\text { (years) }\end{array}$ & Gender & $\begin{array}{l}\text { Adverse } \\
\text { events }\end{array}$ & $\begin{array}{l}\text { Iloperidone } \\
\text { related }\end{array}$ & Conclusion \\
\hline $\begin{array}{l}\text { Achalia and } \\
\text { Andrade }^{59}\end{array}$ & $\begin{array}{l}\text { lloperidone } \\
8-16 \mathrm{mg} / \text { day }\end{array}$ & 1 & $\begin{array}{l}\text { Case } \\
\text { report }\end{array}$ & India & 29 & Male & VPCs & Probably & $\begin{array}{l}\text { Clinically significant and } \\
\text { symptomatically distressing; } \\
\text { diagnosed as VPC. It may } \\
\text { be an uncommon adverse } \\
\text { effect of iloperidone, } \\
\text { possibly mediated by } \\
\text { iloperidone-induced alpha 2c } \\
\text { adrenoceptor blockade. }\end{array}$ \\
\hline Das et $\mathrm{al}^{70}$ & $\begin{array}{l}\text { lloperidone } \\
6-12 \mathrm{mg} \\
2 \times / \text { day }\end{array}$ & 57 & $\begin{array}{l}\text { Case } \\
\text { series }\end{array}$ & India & $17-39$ & $\begin{array}{l}\text { Not } \\
\text { reported }\end{array}$ & $\begin{array}{l}23 \text { patients nasal } \\
\text { congestion, } \\
8 \text { hypotension, } \\
10 \text { fatigue } \\
\text { and dizziness, } \\
4 \text { dry mouth, } \\
4 \text { weight gain, } \\
3 \text { tachycardia, } \\
2 \text { mild } \\
\text { hypoglycemia }\end{array}$ & Probably & $\begin{array}{l}\text { Adverse events were } \\
\text { experienced after taking } \\
\text { iloperidone for at least } \\
4 \text { weeks. Nasal congestion } \\
\text { was the most extensive and } \\
\text { frequent complaint in this } \\
\text { specific population. }\end{array}$ \\
\hline Dutta et $a^{160}$ & $\begin{array}{l}\text { lloperidone } \\
8 \mathrm{mg} / \text { day }\end{array}$ & I & $\begin{array}{l}\text { Case } \\
\text { report }\end{array}$ & India & 35 & Female & Galactorrhea & Yes & $\begin{array}{l}\text { lloperidone can cause } \\
\text { hyperprolactinemic } \\
\text { galactorrhea even at } \\
\text { low dosage and after a } \\
\text { considerable period into the } \\
\text { treatment. }\end{array}$ \\
\hline Freeman et $\mathrm{al}^{71}$ & $\begin{array}{l}\text { lloperidone } \\
8 \mathrm{mg} 2 \times / \text { day }\end{array}$ & 2 & $\begin{array}{l}\text { Case } \\
\text { series }\end{array}$ & USA & 22,21 & Males & $\begin{array}{l}\text { Retrograde } \\
\text { ejaculation }\end{array}$ & Yes & $\begin{array}{l}\text { Clinicians should be aware } \\
\text { of the potential for newer } \\
\text { antipsychotics with strong } \\
\text { alpha I blockade such } \\
\text { as iloperidone to cause } \\
\text { retrograde ejaculation as an } \\
\text { adverse event. }\end{array}$ \\
\hline Muzyk et $\mathrm{al}^{72}$ & $\begin{array}{l}\text { lloperidone } \\
\mathrm{I}-4 \mathrm{mg} 2 \times / \text { day }\end{array}$ & I & $\begin{array}{l}\text { Case } \\
\text { report }\end{array}$ & USA & 24 & Male & Angioedema & $\begin{array}{l}\text { Yes (iloperidone } \\
\text { and haloperidol } \\
\text { association) }\end{array}$ & $\begin{array}{l}\text { This case revealed a } \\
\text { potential interaction of drugs } \\
\text { (iloperidone and haloperidol) } \\
\text { and highlighted the risk of } \\
\text { cross-sensitivity between } \\
\text { different antipsychotics in } \\
\text { the cardiovascular system. }\end{array}$ \\
\hline Ravani et $\mathrm{al}^{73}$ & $\begin{array}{l}\text { lloperidone } \\
\text { I-8 mg/day }\end{array}$ & 5 & $\begin{array}{l}\text { Case } \\
\text { series }\end{array}$ & India & $\begin{array}{l}31,29,19, \\
30,32\end{array}$ & Males & $\begin{array}{l}\text { Ejaculatory } \\
\text { dysfunction }\end{array}$ & Yes & $\begin{array}{l}\text { The ejaculatory dysfunctions } \\
\text { following treatment with } \\
\text { iloperidone could be due } \\
\text { to the blocking of alpha I } \\
\text { adrenergic receptor. }\end{array}$ \\
\hline $\begin{array}{l}\text { Rodriguez } \\
\text { et } \mathrm{al}^{74}\end{array}$ & $\begin{array}{l}\text { lloperidone } \\
6 \mathrm{mg} / \text { day }\end{array}$ & 1 & $\begin{array}{l}\text { Case } \\
\text { report }\end{array}$ & USA & 42 & Male & Priapism & Yes & $\begin{array}{l}\text { This case highlights } \\
\text { important risk factors that } \\
\text { should be considered when } \\
\text { using iloperidone given it is a } \\
\text { potent blocker of the alpha } \\
\text { adrenergic receptor action. }\end{array}$ \\
\hline
\end{tabular}

Abbreviation: VPC, ventricular premature contraction.

PANSS-P and PANSS-GP subscales and CGI-S score was observed for iloperidone in different doses.

In the third study, researchers randomized 706 patients to iloperidone (12-16 $\mathrm{mg} /$ day), iloperidone (20-24 mg/ day), risperidone (6-8 $\mathrm{mg} /$ day) or placebo. Compared with placebo, the iloperidone $20-24 \mathrm{mg} /$ day $(P<0.010)$ and risperidone groups $(P<0.001)$ demonstrated statistically significant improvement in the primary outcome (BPRS changes from baseline). The iloperidone $20-24 \mathrm{mg} /$ day group also resulted in significant reductions in PANSS-T, 
PANSS-P, PANSS-N and CGI-S scores compared with placebo. Lower doses of iloperidone (12-16 mg/day group) did not result in a significant improvement in the BPRS, although they did lead to significant improvement on the CGI-S $(P<0.028)$. Citrome et $\mathrm{l}^{52}$ conducted a post hoc analysis of all four abovementioned RCTs $(n=2,401)$, using an intention-to-treat analysis, and showed that iloperidone (10-16 and 20-24 mg/day) was associated with significant improvements on all mentioned scales compared with placebo.

Furthermore, three other RCTs were recently published. ${ }^{53-56}$ Potkin et $\mathrm{al}^{53}$ have investigated the impact of iloperidone ( 8,12 and $24 \mathrm{mg} /$ day) in 158 patients (18-65 years), compared to ziprasidone or quetiapine in heart rate-corrected QT interval. The results showed no clinically concerning changes in all evaluated groups, and the adverse events reported in the iloperidone group were mild and did not lead to further sequelae.

The REPRIEVE study (A Randomized Trial of Iloperidone for Prevention of Relapse in Schizophrenia), conducted by Weiden et al, ${ }^{54}$ randomized 303 patients to iloperidone (4-12 mg, twice daily) or placebo for 24 weeks. Apart from changes in psychometric scales, such as PANSS-T, where iloperidone showed significant improvements compared to placebo $(P<0.05)$, the authors assessed the mean time to relapse. Results showed a mean of 71 days for placebo and 139 days for iloperidone $(P<0.0001)$. Flexible dosing of iloperidone for maintenance-phase therapy (modal dose: $12 \mathrm{mg} /$ day) was effective in preventing relapse in subjects previously stabilized on iloperidone.

Finally, the study of Weiden et $\mathrm{al}^{56}$ and Citrome et al ${ }^{55}$ was a 12 -week, open-label trial with 500 patients (43.3 \pm 11.0 years), which evaluated the gradual- or immediate-switch strategies from risperidone, olanzapine or aripiprazole to iloperidone of patients experiencing inadequate efficacy and/or poor tolerability. Patients were randomized to switch to iloperidone, either gradually (down-titration of current therapy over the first 2 weeks to $50 \%$ on day $1 ; 25 \%$ by week $1 ; 0 \%$ by week 2 ) or immediately. All patients were titrated on iloperidone to $6 \mathrm{mg}$ twice daily by day 4, then, flexibly dosing between 6 and $12 \mathrm{mg}$ twice daily, as needed. The primary outcome was CGI improvement at week 12. Response rates were similar between groups during study periods and confirmed the clinical improvement in both groups without any significant difference in ratings of overall efficacy. However, the immediate-switch method was associated with a greater proportion of dizziness.

\section{Long-term studies on iloperidone effectiveness}

Considering the long-term extension trials ${ }^{57,58}$ with $>662$ patients combined, iloperidone showed a good overall effectiveness profile despite dosing (12-24 mg/day) against placebo and haloperidol. No signs of worsening were observed in any rating scale (PANSS, CGI and BPRS). Laboratory parameters, such as glycemia, lipid profile (cholesterol, triglycerides, high-density lipoprotein [HDL] and low-density lipoprotein [LDL]), prolactin level and weight, did not change drastically during the study and values were, overall, within normal.

Therefore, published studies have demonstrated that iloperidone has acute and long-term efficacy for schizophrenia, especially when compared to placebo, and can be considered similar to other active drugs such as risperidone, haloperidol and ziprasidone.

\section{Safety and tolerability}

Almost all included RCTs reported data on safety and tolerability profiles of iloperidone (Table 1). Observational studies (Table 2) were gathered to contribute as evidence for clinical practice.

The most commonly reported adverse events (reported by $>5 \%$ of patients in the studies) were dizziness (especially when switching from another antipsychotic to iloperidone without gradual titration), sedation, weight gain, dry mouth, nasal congestion, hypotension, headache, nausea, sleep disorders (insomnia, somnolence) and heart-related changes (tachycardia, palpitations and electrocardiogram [ECG] alterations). EPS was reported in three trials, with rates ranging from $0.6 \%$ to $8 \%$. Compared to other drugs, haloperidol showed a higher propensity to cause EPS, tremor, akathisia and dystonia. Risperidone was also more associated with EPS, tremor and somnolence than iloperidone.

As expected, owing to the mechanism of action of iloperidone, this drug has a more favorable EPS and akathisia profile than other D2/5HT2A antagonists. The adverse events profile of iloperidone appears to be a cross between that of ziprasidone and risperidone. Compared with ziprasidone, iloperidone caused similar QTc interval prolongation ${ }^{53}$ but with greater potential for weight gain, which should be taken into account when considering patients individual characteristics. Rates from $4 \%$ to $13 \%$ were found for iloperidone causing sedation, which is also an important concern for patients and should be considered during therapeutic decision-making. Although no cases of iloperidone-associated sudden death due to arrhythmias have been reported, avoidance of this drug may be prudent for patients who are medically susceptible to 
heart diseases or for patients taking concomitant medications that lengthen the QT interval. These precautions are similar to those for ziprasidone..$^{39,40,59}$ So far, only one case of ventricular premature contractions has been published and is possibly related to iloperidone inducing alpha $2 \mathrm{c}$ receptor blockage. ${ }^{59}$

Furthermore, risperidone is noted to have the highest propensity of all SGA agents to cause hyperprolactinemia, with potential to cause oligomenorrhea or amenorrhea in women and erectile dysfunction in men. These adverse events were considered uncommon reactions to iloperidone. Two observational studies referred to ejaculatory dysfunction, reported in men from 20 to 30 years old, which was also reported in an extension trial ${ }^{57}$ in $\sim 2 \%$ of the patients and appears to be due to the blocking of alpha 1 adrenergic receptors. Moreover, one case of galactorrhea was reported but is considered rare.$^{60}$ However, iloperidone causes significantly more orthostatic hypotension than risperidone, and this may be a concern for some patients and requires the use of divided doses and gradual dosage increases (titration). ${ }^{40}$ Some other mild events, such as nasal congestion, dry mouth and sleep disorders, seem to stabilize over time, as observed in the extension trials, and can be well managed.

It is worth noting that there is a potential interaction of the drugs iloperidone and haloperidol, leading to angioedema, which highlights the risk of cross-sensitivity of antipsychotics to cause cardiovascular problems. Concomitant medications must be closely monitored; the dose of iloperidone needs to be reduced in the presence of other drugs, especially drugs that are strong CYP450 inhibitors. ${ }^{53,59,61}$ So far, no evidence on iloperidone causing acute kidney injury (AKI) is available. Since other atypical antipsychotics (quetiapine, risperidone and olanzapine) are linked to increased risk of hospitalization for AKI in elderly patients, caution for the use of iloperidone in elderly is recommended. ${ }^{62}$

Considering the tolerability profile of iloperidone, discontinuation rates ranged from $3 \%$ to almost $61 \%$. These differences may be due to the size of the studies, population characteristics and follow-up trials. Rates were similar to placebo and active comparators in all clinical trials $(P>0.05)$ and were more related, in order, to consent withdrawal, unsatisfactory therapeutic response and adverse events. In the trial published by Cutler et al, ${ }^{47} \sim 16 \%$ of patients discontinued due to adverse events. Other causes of treatment dropout were consent withdrawal (58\%) and inefficacy (21\%). In the study of Potkin et al, ${ }^{51}$ iloperidone was discontinued by $\sim 25 \%$ of patients in each group due to unsatisfactory effect and by $\sim 7 \%$ due to adverse events. In long-term trials, Cutler et $\mathrm{al}^{57}$ showed that less than half of the patients $(41.6 \%)$ completed the extension phase: 25 patients discontinued owing to adverse events, 36 withdrew consent, eleven had unsatisfactory therapeutic response and 18 were lost during follow-up. In the study of Kane et $\mathrm{al}^{58}$, discontinuation rates owing to adverse events of iloperidone were inferior to those from haloperidol (3.8\% and $7.6 \%$, respectively). However, more patients from iloperidone withdrew consent $(14.5 \%$ iloperidone and $8.5 \%$ haloperidol) and a similar number discontinued due to therapeutic failure $(\sim 10 \%) .^{57,58}$

Overall, iloperidone was considered reasonably tolerable and to have a promising safety profile among adult patients, and no further serious events were reported. No safety data are so far available for children and adolescents. ${ }^{42}$ Other previous studies, systematic reviews and meta-analyses showed that iloperidone is an acceptable drug, even when compared to placebo or other antipsychotics, especially in terms of modest weight gain, no medically important changes in lipid and glucose levels and little in the way of prolactin elevation and EPS. ${ }^{31,39,52,63}$

\section{Pricing}

Schizophrenia therapeutics yield $\$ 6.3$ billion in market sales per year around the world, and this will grow to $\$ 7.9$ billion by 2022. ${ }^{64}$ Currently, there is no formal pharmacoeconomic study on the cost-effectiveness of iloperidone for treating schizophrenia. An estimated monthly acquisition cost comparison among usual maintenance doses of atypical antipsychotics showed that the cost of iloperidone of $\$ 630$ is $\$ 50$ more than that of asenapine, \$200 more than that of ziprasidone and \$400 more than the cost of generic risperidone. ${ }^{30,40}$ Thus, when referring only to acquisition costs of iloperidone, the higher price can hamper its use in clinical practice. However, it is important to compare the impact of iloperidone with other antipsychotics in reducing adverse events, hospitalization and ineffectivity. Thus, pharmacoeconomic studies should be performed.

\section{Place in therapy}

Atypical antipsychotics are now recommended as first-line agents for the treatment of patients with schizophrenia. Con-

Table 3 lloperidone clinical profile

\begin{tabular}{ll}
\hline Advantages & Disadvantages \\
\hline Low propensity to cause EPS & $\begin{array}{l}\text { Requires slow titration to therapeutic } \\
\text { doses, which may delay onset of } \\
\text { therapeutic effect } \\
\text { Risk of orthostatic hypotension, }\end{array}$ \\
Low propensity to cause & sedation and dizziness \\
prolactin increase & Not indicated for patients with any risk \\
Low propensity to change & for clinical QTc prolongation \\
lipid and glycemic profile & Potential interactions with agents that \\
No dose adjustment required & inhibit or induce CYP2D6 and CYP3A4 \\
\hline
\end{tabular}

Abbreviation: EPS, extrapyramidal symptoms. 
sidering all exposed, iloperidone has favorable properties that may promote and spread its use. Table 3 shows a summary of the advantages and disadvantages of this drug.

Iloperidone is clearly more effective than placebo at dosages exceeding $8 \mathrm{mg}$ daily, with increasing efficacy noted at dosages of up to 20-24 mg daily, given in equally divided doses. Furthermore, this drug appears to be as effective as haloperidol, risperidone and ziprasidone when it comes to improving results in validated psychometric scales of schizophrenia symptoms.

Iloperidone seems an attractive choice, particularly for patients whose compliance is limited by side effects that occur more frequently with other antipsychotics. Further systematic reviews and meta-analyses have also shown that iloperidone did not significantly cause EPS and akathisia, increased prolactin or changed laboratory parameters when compared to placebo and other antipsychotics.

Poor or non-adherence behavior is common in psychiatry (rates $>50 \%$ ) and attributed to lack of efficacy, poor tolerability and patient's denial of the disease (in approximately one-third to one-half of diagnosed patients). ${ }^{65,66}$ For allcause discontinuation, iloperidone shows a tolerable profile compared to haloperidol, lurasidone, sertindole and ziprasidone, ${ }^{31,63}$ and despite producing some significant weight gain, this drug seems to be well accepted among patients. However, the slow titration schedule, adapted to reduce dizziness, sedation and orthostatic hypotension, may limit the use of this agent in an acute setting. The usual target effective range is $12-24 \mathrm{mg}$ daily, given in two divided doses. The maximum labeled dose of iloperidone is $12 \mathrm{mg}$ twice daily. Furthermore, given the capacity of iloperidone to extend QTc interval on ECG, it is not recommended for use in patients with heart-related diseases or in coadministration with other QT-prolonging drugs. ${ }^{31,63,67,68}$ In this context, long-acting injectable formulations (LAIs) have been identified as a means of improving adherence, reducing dose-related sideeffects due to lower peak of drug plasma levels and helping to prevent relapse. Currently, LAIs of fluphenazine, haloperidol, olanzapine, risperidone, aripiprazole and paliperidone are available for use. The iloperidone crystalline LAI is still under investigation in Phase II and III trials with a dosing interval of 28 days. ${ }^{65,66,69}$

Therefore, available evidence suggests that iloperidone may be classified as having low health-related risks and should be incorporated into clinical practice with few contraindications. However, drug acquisition costs certainly limit its use. Further reasonable pharmacoeconomic studies, resource utilization and pricing should be reconsidered to provide more accessible therapeutic options to treat schizophrenia. Schizophrenia is considered one of the worst mental disorders worldwide, with a very disabling prognosis. Continuing to provide novel treatment options may help patients to overcome some limits and experience recovery and independence. Other studies evaluating patients' outcomes of quality of life, general functioning and satisfaction with treatment would also help to define the place of iloperidone in therapy.

\section{Author contributions}

RP and FFL designed the study and wrote the protocol. FST and AW screened and abstracted publications. FST, AW, FFL and RP analyzed data and wrote the manuscript. All authors contributed toward data analysis, drafting and critically revising the paper and agree to be accountable for all aspects of the work. All authors reviewed the manuscript for accuracy and scientific content.

\section{Disclosure}

The authors report no conflicts of interest in this work.

\section{References}

1. Moher D, Liberati A, Tetzlaff J, Altman DG. The PRISMA Group Preferred reporting items for systematic reviews and metaanalyses: the PRISMA statement. J Clin Epidemiol. 2009;62:1006-1012.

2. Higgins JPT, Green S. Cochrane Handbook for Systematic Reviews of Interventions Version 5.1.0. The Cochrane Collaboration, 2011.

3. Millan MJ, Fone K, Steckler T, Horan WP. Negative symptoms of schizophrenia: clinical characteristics, pathophysiological substrates, experimental models and prospects for improved treatment. Eur Neuropsychopharmacol. 2014;24(5):645-692.

4. Owen MJ, Sawa A, Mortensen PB. Schizophrenia. Lancet. 2016; 388(10039):86-97.

5. Hartling L, Abou-Setta AM, Dursun S, Mousavi SS, Pasichnyk D, Newton AS. Antipsychotics in adults with schizophrenia: comparative effectiveness of first-generation versus second-generation medications: a systematic review and meta-analysis. Ann Intern Med. 2012;157(7):498-511.

6. Lieberman JA, Perkins D, Belger A, et al. The early stages of schizophrenia: speculations on pathogenesis, pathophysiology, and therapeutic approaches. Biol Psychiatry. 2001;50(11):884-897.

7. Tandon R. Schizophrenia and other psychotic disorders in DSM-5. Clin Schizophr Relat Psychoses. 2013;7(1):16-19.

8. Tandon R, Gaebel W, Barch DM, et al. Definition and description of schizophrenia in the DSM-5. Schizophr Res. 2013;150(1):3-10.

9. Asenjo Lobos C, Komossa K, Rummel-Kluge C, et al. Clozapine versus other atypical antipsychotics for schizophrenia. Cochrane Database Syst Rev. 2010;11:CD006633.

10. Leucht S, Corves C, Arbter D, Engel RR, Li C, Davis JM. Secondgeneration versus first-generation antipsychotic drugs for schizophrenia: a meta-analysis. Lancet. 2009;373(9657):31-41.

11. Simeone JC, Ward AJ, Rotella P, Collins J, Windisch R. An evaluation of variation in published estimates of schizophrenia prevalence from 1990 horizontal line 2013: a systematic literature review. BMC Psychiatry. 2015;15:193.

12. Ince P, Haddock G, Tai S. A systematic review of the implementation of recommended psychological interventions for schizophrenia: rates, barriers, and improvement strategies. Psychol Psychother. 2016;89(3):324-350. 
13. Laurens KR, Cullen AE. Toward earlier identification and preventative intervention in schizophrenia: evidence from the London Child Health and Development Study. Soc Psychiatry Psychiatr Epidemiol. 2016;51(4):475-491.

14. Fusar-Poli P, Carpenter WT, Woods SW, McGlashan TH. Attenuated psychosis syndrome: ready for DSM-5.1? Annu Rev Clin Psychol. 2014;10:155-192.

15. Cloutier M, Aigbogun MS, Guerin A, et al. The economic burden of schizophrenia in the United States in 2013. JClin Psychiatry. 2016;77(6): 764-771.

16. Siever LJ, Davis KL. The pathophysiology of schizophrenia disorders: perspectives from the spectrum. Am J Psychiatry. 2004;161(3): 398-413.

17. Cioffi CL. Modulation of NMDA receptor function as a treatment for schizophrenia. Bioorg Med Chem Lett. 2013;23(18):5034-5044.

18. Coyle JT. The glutamatergic dysfunction hypothesis for schizophrenia. Harv Rev Psychiatry. 1996;3(5):241-253.

19. Javitt DC. Glutamate and schizophrenia: phencyclidine, N-methylD-aspartate receptors, and dopamine-glutamate interactions. Int Rev Neurobiol. 2007;78:69-108.

20. Landek-Salgado MA, Faust TE, Sawa A. Molecular substrates of schizophrenia: homeostatic signaling to connectivity. Mol Psychiatry. 2016;21(1):10-28.

21. Sigmundsson T, Suckling J, Maier M, et al. Structural abnormalities in frontal, temporal, and limbic regions and interconnecting white matter tracts in schizophrenic patients with prominent negative symptoms. $\mathrm{Am}$ J Psychiatry. 2001;158(2):234-243.

22. Ellison-Wright I, Bullmore E. Meta-analysis of diffusion tensor imaging studies in schizophrenia. Schizophr Res. 2009;108(1-3):3-10.

23. Olabi B, Ellison-Wright I, McIntosh AM, Wood SJ, Bullmore E, Lawrie SM. Are there progressive brain changes in schizophrenia? A meta-analysis of structural magnetic resonance imaging studies. Biol Psychiatry. 2011;70(1):88-96.

24. Davis KL, Stewart DG, Friedman JI, et al. White matter changes in schizophrenia: evidence for myelin-related dysfunction. Arch Gen Psychiatry. 2003;60(5):443-456.

25. Moore TH, Zammit S, Lingford-Hughes A, et al. Cannabis use and risk of psychotic or affective mental health outcomes: a systematic review. Lancet. 2007;370(9584):319-328.

26. Roussos P, Haroutunian V. Schizophrenia: susceptibility genes and oligodendroglial and myelin related abnormalities. Front Cell Neurosci. 2014;8:5.

27. Hall J, Trent S, Thomas KL, O’Donovan MC, Owen MJ. Genetic risk for schizophrenia: convergence on synaptic pathways involved in plasticity. Biol Psychiatry. 2015;77(1):52-58.

28. Muller N, Myint AM, Schwarz MJ. Inflammation in schizophrenia. $A d v$ Protein Chem Struct Biol. 2012;88:49-68.

29. Drexhage RC, Weigelt K, van Beveren N, et al. Immune and neuroimmune alterations in mood disorders and schizophrenia. Int Rev Neurobiol. 2011;101:169-201.

30. Bawa P, Pradeep P, Kumar P, Choonara YE, Modi G, Pillay V. Multitarget therapeutics for neuropsychiatric and neurodegenerative disorders. Drug Discov Today. Epub 2016 Aug 6.

31. Leucht S, Cipriani A, Spineli L, et al. Comparative efficacy and tolerability of 15 antipsychotic drugs in schizophrenia: a multiple-treatments meta-analysis. Lancet. 2013;382(9896):951-962.

32. Winlow W, Profit L, Chrisp P. Aripiprazole: the evidence of its therapeutic impact in schizophrenia. Core Evid. 2006;1(4):251-264.

33. Kantrowitz J, Citrome L. Paliperidone: the evidence of its therapeutic value in schizophrenia. Core Evid. 2008;2(4):261-271.

34. Bruijnzeel D, Suryadevara U, Tandon R. Antipsychotic treatment of schizophrenia: an update. Asian J Psychiatr. 2014;11:3-7.

35. Miyamoto S, Miyake N, Jarskog LF, Fleischhacker WW, Lieberman JA. Pharmacological treatment of schizophrenia: a critical review of the pharmacology and clinical effects of current and future therapeutic agents. Mol Psychiatry. 2012;17(12):1206-1227.
36. Tandon R. Antipsychotics in the treatment of schizophrenia: an overview. J Clin Psychiatry. 2011;72(suppl 1):4-8.

37. Keshavan MS, Lawler AN, Nasrallah HA, Tandon R. New drug developments in psychosis: challenges, opportunities and strategies. Prog Neurobiol. Epub 2016 Aug 9.

38. Correll CU, Leucht S, Kane JM. Lower risk for tardive dyskinesia associated with second-generation antipsychotics: a systematic review of 1-year studies. Am J Psychiatry. 2004;161(3):414-425.

39. Arif SA, Mitchell MM. Iloperidone: a new drug for the treatment of schizophrenia. Am J Health Syst Pharm. 2011;68(4):301-308.

40. Dopheide JA. Iloperidone: does it have a meaningful place in therapy? Am J Health Syst Pharm. 2011;68(4):297.

41. Corbett R, Griffiths L, Shipley JE, et al. Iloperidone: preclinical profile and early clinical evaluation. CNS Drug Rev. 1997;3(2):120-147.

42. Orsolini L, Tomasetti C, Valchera A, et al. An update of safety of clinically used atypical antipsychotics. Expert Opin Drug Saf. 2016;15(10):1329-1347.

43. Citrome L. Iloperidone: chemistry, pharmacodynamics, pharmacokinetics and metabolism, clinical efficacy, safety and tolerability, regulatory affairs, and an opinion. Expert Opin Drug Metab Toxicol. 2010;6(12):1551-1564.

44. Mortimer AM. Symptom rating scales and outcome in schizophrenia. Br J Psychiatry Suppl. 2007;50:s7-s14.

45. Suzuki T, Uchida H, Sakurai H, et al. Relationships between global assessment of functioning and other rating scales in clinical trials for schizophrenia. Psychiatry Res. 2015;227(2-3):265-269.

46. Leucht S. Measurements of response, remission, and recovery in schizophrenia and examples for their clinical application. J Clin Psychiatry. 2014;75(suppl 1):8-14.

47. Cutler AJ, Kalali AH, Weiden PJ, Hamilton J, Wolfgang CD. Four-week, double-blind, placebo- and ziprasidone-controlled trial of iloperidone in patients with acute exacerbations of schizophrenia. J Clin Psychopharmacol. 2008;28(7 suppl 1):S20-S28.

48. Lavedan C, Volpi S, Polymeropoulos MH, Wolfgang CD. Effect of a ciliary neurotrophic factor polymorphism on schizophrenia symptom improvement in an iloperidone clinical trial. Pharmacogenomics. 2008;9(3):289-301.

49. Thompson A, Lavedan C, Volpi S. Absence of weight gain association with the HTR $2 \mathrm{C}-759 \mathrm{C} / \mathrm{T}$ polymorphism in patients with schizophrenia treated with iloperidone. Psychiatry Res. 2010;175(3):271-273.

50. Volpi S, Heaton $\mathrm{C}$, MacK K, et al. Whole genome association study identifies polymorphisms associated with QT prolongation during iloperidone treatment of schizophrenia. Mol Psychiatry. 2009;14(11):1024-1031.

51. Potkin SG, Litman RE, Torres R, Wolfgang CD. Efficacy of iloperidone in the treatment of schizophrenia: initial phase 3 studies. J Clin Psychopharmacol. 2008;28(7 suppl 1):S4-S11.

52. Citrome L, Meng X, Hochfeld M, Stahl SM. Efficacy of iloperidone in the short-term treatment of schizophrenia: a post hoc analysis of pooled patient data from four phase III, placebo- and active-controlled trials. Hum Psychopharmacol. 2012;27(1):24-32.

53. Potkin SG, Preskorn S, Hochfeld M, Meng X. A thorough QTe study of 3 doses of iloperidone including metabolic inhibition via CYP2D6 and/or CYP3A4 and a comparison to quetiapine and ziprasidone. J Clin Psychopharmacol. 2013;33(1):3-10.

54. Weiden PJ, Manning R, Wolfgang CD, et al. A randomized trial of iloperidone for prevention of relapse in schizophrenia: the REPRIEVE study. CNS Drugs. 2016;30(8):735-747.

55. Citrome L, Weiden PJ, Alva G, et al. Switching to iloperidone: an omnibus of clinically relevant observations from a 12-week, openlabel, randomized clinical trial in 500 persons with schizophrenia. Clin Schizophr Relat Psychoses. 2015;8(4):183-195.

56. Weiden PJ, Citrome L, Alva G, et al. A trial evaluating gradual- or immediate-switch strategies from risperidone, olanzapine, or aripiprazole to iloperidone in patients with schizophrenia. Schizophr Res. 2014;153(1-3):160-168. 
57. Cutler AJ, Kalali AH, Mattingly GW, Kunovac J, Meng X. Long-term safety and tolerability of iloperidone: results from a 25-week, open-label extension trial. CNS Spectr. 2013;18(1):43-54.

58. Kane JM, Lauriello J, Laska E, Di Marino M, Wolfgang CD. Longterm efficacy and safety of iloperidone: results from 3 clinical trials for the treatment of schizophrenia. J Clin Psychopharmacol. 2008;28(7 suppl 1):S29-S35.

59. Achalia R, Andrade C. Ventricular premature contractions associated with iloperidone. Indian J Psychiatry. 2013;55(2):195-196.

60. Dutta A, Barua S, Dan A, Chakraborty K, Mandal M. Iloperidoneinduced galactorrhea in a middle-aged female. Indian J Psychol Med. 2012;34(4):396-398.

61. Muzyk AJ, Cvelich RG, Kincaid BR, Preud'homme XA. Angioedema occurring in patient prescribed iloperidone and haloperidol: a crosssensitivity reaction to antipsychotics from different chemical classes. $J$ Neuropsychiatry Clin Neurosci. 2012;24(2):E40-E41.

62. Hwang YJ, Dixon SN, Reiss JP, et al. Atypical antipsychotic drugs and the risk for acute kidney injury and other adverse outcomes in older adults: a population-based cohort study. Ann Intern Med. 2014;161(4):242-248.

63. Tonin FS, Piazza T, Wiens A, Fernandez-Llimos F, Pontarolo R. Adverse events and treatment failure leading to discontinuation of recently approved antipsychotic drugs in schizophrenia: a network meta-analysis Schizophr Res. 2015;169(1-3):483-485.

64. Gohil K, Carramusa B. Schizophrenia therapy options increasing. P T. 2014;39(9):646-647.

65. Aldridge MA. Addressing non-adherence to antipsychotic medication: a harm-reduction approach. J Psychiatr Ment Health Nurs. 2012;19(1):85-96.
66. Cerovecki A, Musil R, Klimke A, et al. Withdrawal symptoms and rebound syndromes associated with switching and discontinuing atypical antipsychotics: theoretical background and practical recommendations. CNS Drugs. 2013;27(7):545-572.

67. Citrome L. A systematic review of meta-analyses of the efficacy of oral atypical antipsychotics for the treatment of adult patients with schizophrenia. Expert Opin Pharmacother. 2012;13(11):1545-1573.

68. De Hert M, Yu W, Detraux J, Sweers K, van Winkel R, Correll CU. Body weight and metabolic adverse effects of asenapine, iloperidone, lurasidone and paliperidone in the treatment of schizophrenia and bipolar disorder: a systematic review and exploratory meta-analysis. CNS Drugs. 2012;26(9):733-759.

69. Kirson NY, Weiden PJ, Yermakov S, et al. Efficacy and effectiveness of depot versus oral antipsychotics in schizophrenia: synthesizing results across different research designs. J Clin Psychiatry. 2013;74(6):568-575.

70. Das S, Saha I, Mondal S, Bandyopadhyay S. Nasal congestion with iloperidone therapy in a case series. JYoung Pharm. 2013;5(3):108-109.

71. Freeman SA. Iloperidone-induced retrograde ejaculation. Int Clin Psychopharm. 2013;28(3):156.

72. Muzyk AJ, Cvelich RG, Kincaid BR, Preud'homme XA. Angioedema occurring in patient prescribed iloperidone and haloperidol:A crosssensitivity reaction to antipsychotics from different chemical classes. J Neuropsychiatry Clin Neurosci. 2012;24(2):E40-E41.

73. Ravani NN, Katke PH. Iloperidone-induced ejaculatory dysfunction: a case series. Indian J Psychiatry. 2016;58(1):87-89.

74. Rodriguez-Cabezas LA, Kong BY, Agarwal G. Priapism associated with iloperidone: a case report. Gen Hosp Psychiatry. 2014;36(4): 451.e455-451.e456

\section{Core Evidence}

\section{Publish your work in this journal}

Core Evidence is an international, peer-reviewed open-access journa evaluating the evidence underlying the potential place in therapy of drugs throughout their development lifecycle from preclinical to post launch. The focus of each review is to evaluate the case for a new drug or class in outcome terms in specific indications and patient groups.

\section{Dovepress}

The manuscript management system is completely online and includes a very quick and fair peer-review system, which is all easy to use. Visit http://www.dovepress.com/testimonials.php to read real quotes from published authors. 